David Estlund

Brown University, Providence

e-mail: David_Estlund@brown.edu

\title{
Dlaczego nie epistokracja?
}

DOI: http://dx.doi.org/10.12775/RF.2017.011

\section{Wprowadzenie}

Mimo że pogląd głoszący, że to osoby mądre powinny sprawować władzę, wydaje się dość naturalny, obecnie powszechnie się go odrzuca. Jednym z powodów takiego stanu rzeczy jest to, że w opinii wielu ludzi metoda sprawowania władzy powinna być możliwa do uzasadnienia w sposób powszechnie akceptowalny. Zważywszy istnienie szeregu rozsądnych argumentów przypisujących mądrość zupełnie innym podmiotom (jak też wiele innych kwestii), wątpliwe jest, by rządy osób mądrych spełniły kryterium uzasadnienia powszechnie akceptowalnego. $Z$ drugiej strony bez wątpienia dobre wykształcenie obejmujące, powiedzmy, wiedzę z zakresu polityki, historii, ekonomii, bliski kontakt z osobami z różnych środowisk itd. zasadniczo zwiększa zdolność jednostek do mądrego rządzenia, przynajmniej założywszy pewną dozę dobrej woli $\mathrm{z}$ ich strony ( $\mathrm{w}$ przeciwnym razie te same $\mathrm{w}$ sobie neutralne środki mogłyby uczynić osobę złą jeszcze niebezpieczniejszą). Czy zatem nie powinniśmy przyjąć, że osoby mające takie wykształcenie powinny dysponować większą liczbą głosów od pozostałych? Czy jedynym dostępnym kontrargumentem jest przypuszczenie, że ktokolwiek ma większą władzę od pozostałych, będzie niesprawiedliwie fawory-

"Źródło: Why Not Epistocracy?, w: Desire, Identity and Existence: Essays in Honor of T.M. Penner, red. N. Reshotko, Academic Printing and Publishing, Edmonton 2003, s. 53-69. Publikacja przekładu za zgodą autora i wydawnictwa [przyp. tłum.]. 
zował siebie? A gdyby dało się wyeliminować takie zagrożenie, czy nie powinniśmy wówczas zgodzić się na rządy osób mądrych?

Jeżeli niektóre rezultaty działań politycznych są lepsze od innych, to z pewnością niektórzy obywatele przewyższają innych (a przynajmniej nie są od nich gorsi) pod względem mądrości oraz dobrej wiary w zabieganiu o realizację takich rezultatów. Jeśli jest tak w rzeczywistości, to stanowi to mocny argument za tym, by właśnie takie osoby podejmowały decyzje. Na potrzeby tego eseju nazwiemy je wiedzącymi lub mądrymi. Formę rządów przyznającą im władzę możemy określić epistokracja, owych władców zaś epistokratami, nawiązując do greckiego słowa epistêmê oznaczającego wiedzę. Zapewne możliwe jest, że osoba dysponująca wiedzą o tym, które działanie jest najlepsze, nie zdecydowałaby się go podjąć. Taka możliwość podważałaby wartość epistokracji. Dla uproszczenia swoich rozważań przyjmę jednak (zgodnie z tym, co twierdził np. Sokrates ${ }^{1}$ ), że ludzie wiedzący czyniliby to, co uznaliby za najlepsze (powrócę do tego problemu jeszcze później). Ewentualnie, jeśli jest to zbyt mocne założenie, przyjmijmy po prostu, że owi potencjalni epistokraci mieliby motywację do kierowania się dobrem publicznym. Tak więc, na potrzeby toczonej tu argumentacji przyjmę, że niektóre osoby są mądrzejsze od pozostałych we wskazany już sposób, oraz że mając sposobność, czyniłyby to, co uznałyby za najlepsze dla państwa. Fundamentalne pytanie spoczywające u podstaw bardziej szczegółowej kwestii, na której zamierzam się tu skupić, brzmi: dlaczego takie mądrzejsze osoby nie powinny rządzić, dlaczego nie epistokracja? Tym bardziej szczegółowym przedmiotem moich rozważań i krytyki jest teza głosząca, że osoby lepiej wykształcone rządziłyby mądrzej, a zatem powinny dysponować większą władzą polityczną pod postacią większej siły głosu od innych wyborców.

Jak wiadomo, myślicielem, który zaproponował przyznanie większej liczby głosów osobom lepiej wykształconym, był John Stuart Mill². Na gruncie filozofii polityki zwykle przyjmuje się, że autorytarny Platon oraz liberalny przeciwnik paternalizmu Mill mają ze sobą niewiele wspólnego. W rzeczywistości Mill był jednak pod znacznym wpływem myśli Platona ${ }^{3}$. To prawda, że ewidentnie sokratejski duch racjonalnej analizy własnego życia i przekonań dogłębnie przenika rozważania Milla i przesądza o charakterystycznej postaci jego wpływowej wizji

1 Zob. Platon, Protagoras, przeł. L. Regner, Wydawnictwo Naukowe PWN, Warszawa 1995.

2 J.S. Mill, O rzadzie reprezentacyjnym, przeł. G. Czernicki, Wydawnictwo Dzieł Tanich i Pożytecznych: Drukarnia "Czasu” W. Kirchmayera, Kraków 1866, rozdz. VIII.

Zob. T. Irwin, Mill and the Classical World, w: The Cambridge Companion to Mill (red. J. Skorupski), Cambridge University Press, Cambridge 1997. 
wolności. Wpływ ten jednak był zapewne zapośredniczony przez pisma Platona. Mill wyraźnie sympatyzował z platońską idea, że władza polityczna powinna spoczywać w rękach osób potrafiących sprawować ją najmądrzej i najsprawiedliwiej. Co prawda odnajdujemy ten pogląd także u Sokratesa ${ }^{4}$, jednak w najpełniejszej postaci występuje on w Państwie Platona. Podobnie do Platona Mill sądził, że wyjątkowa mądrość pewnej grupy mniejszościowej usprawiedliwia przyznanie jej większej władzy politycznej. Twierdził on, że obywatele lepiej wykształceni powinni dysponować większą liczbą głosów od reszty, nawet jeśli każdy obywatel powinien mieć prawo głosowania. Rządy osób wykształconych będę nazywał scholokracja, przy czym należy zauważyć, że jej wersja forsowana przez Milla jest dość umiarkowana. Przyjmuje się w niej bowiem powszechność praw wyborczych na zasadzie: jedna osoba - co najmniej jeden głos.

Nie zamierzam stosować tu dość rozpowszechnionego argumentu, zgodnie z którym choć bez wątpienia osoby wykształcone mogłyby rządzić mądrzej od innych, to względy równego szacunku lub bezstronności proceduralnej bezpośrednio i kategorycznie przemawiają przeciwko przyznaniu niektórym ludziom większej liczby głosów niż pozostałym ${ }^{5}$. Nie przeczę (ani też nie zgadzam się), że osoby wykształcone dysponują przypisywaną im przez Milla mądrością, lecz nie zgodzę się, że teza ta może uzasadniać nierówną dystrybucję władzy politycznej. W każdym razie moim celem jest $w$ tym samym stopniu wyjaśnienie Millowskiej koncepcji scholokracji, docenienie jej wagi jako wyzwania rzuconego zasadzie równej siły głosu obywateli, jak też jej krytyka.

Zacznę od wskazania na to, co uważam za tak godne podziwu w Millowskiej propozycji głosowania „wielokrotnego” lub ważonego, które uprzywilejowywałoby osoby lepiej wykształcone. Wpierw rozważę zarzut wysunięty przez Arystotelesa wobec platońskiej idei rządów nielicznej, mądrej elity. $W$ istocie Mill wykorzystuje Arystotelesowski antyelitarny punkt widzenia, by z jego pomocą wzmocnić swą argumentację na rzecz umiarkowanej epistokracji. Następnie rozważę jedną z możliwych krytyk stanowiska Milla, a mianowicie zarzut demograficzny. Na koniec uwypuklę konsekwencje mojej argumentacji dla ideału formalnie równej siły głosu wszystkich obywateli.

4 Teksty te oraz dotyczące ich problemy interpretacyjne są dyskutowane przez Krauta w: R. Kraut, Socrates and the State, Princeton University Press, Princeton NJ 1997, rozdz. 7, podrozdział 8.

5 Zob. R. Arneson, Democratic Rights at National and Workplace Levels, w: The Idea of Democracy, red. D. Copp et al., Cambridge University Press, New York 1993, szczególnie s. 133-138; C. Beitz, Political Equality, Princeton University Press, Princeton NJ 1989, s. 38-40. 


\section{Arystoteles vs epistokracja platońska}

Mimo że łatwiej jest zgodzić się z tezą o istnieniu ekspertów od spraw technicznych, niż z tym, że istnieją też eksperci od szeroko pojętych kwestii praktycznych (w tym moralnych), to jednak nasze rozważania byłyby mniej znaczące z perspektywy władzy praktycznej, gdybyśmy uwzględnili jedynie ekspertyzę techniczną. Na użytek argumentacji przyjmę tu, że występują obydwa typy ekspertów. Jeśli nawet przy takim założeniu uda mi się wykazać możliwość podważenia argumentacji epistokratycznej, dodatkowo wzmocni to doniosłość mojego rozumowania.

Załóżmy zatem, że istnieje nieliczna grupa osób, które dysponują wyjątkowo rozwiniętą praktyczną mądrością o charakterze moralnym, kluczową dla zajmowania się sprawami politycznymi. Przede wszystkim oznacza to, że każda z nich wie lepiej niż ktokolwiek spoza tej grupy, jakie działania polityczne powinny zostać podjęte. W takiej sytuacji może się wydawać, że władza $\mathrm{w}$ państwie powinna być powierzona właśnie tej mądrej grupie, jak też, że wszyscy obywatele powinni mieć przymus czynienia tego, co owa grupa zaleci.

Nawet przypisawszy tak wielką wagę do zdolności podejmowania prawidłowych decyzji, powyższy wniosek wcale nie jest oczywisty, na co wskazują pewne uwagi Arystotelesa ${ }^{6}$. Dla uproszczenia przyjmijmy, że taka mądra grupa składa się tylko z jednej osoby. Nawet przyznając, że słuchanie jej zaleceń prowadziłoby do właściwych działań politycznych częściej niż podążanie za decyzjami jakiejkolwiek innej osoby, decyzje takie mogłyby być jeszcze lepsze, gdyby osoba ta dyskutowała i współdecydowała wraz z kilkoma innymi - powiedzmy kolejnymi najmądrzejszymi członkami społeczeństwa. Wniosek ten jest oczywisty, gdy rozpatrzymy go w kontekście prostych testów niedotyczących kwestii moralnych, jak na przykład zestandaryzowanych testów wyboru używanych podczas egzaminów na studia. Osoba z najlepszym wynikiem $\mathrm{w}$ grupie $\mathrm{z}$ pewnością nie poradziłaby sobie $\mathrm{z}$ takim testem lepiej niż grupa kilku osób mających od niej nieznacznie gorsze wyniki, ale działających wspólnie, nawet jeżeli zwiększenie liczby uczestników testu obniżyłoby średnią kompetencję grupy. Jest wielce prawdopodobne, że ta sama logika stosuje się do decyzji politycznych. Na tej podstawie Arystoteles odrzuca prosty argument głoszący, że władza powinna być powierzona kilku najmądrzejszym osobom, skoro to one wiedzą najlepiej, jakie działania należy podjąć. Pytanie dotyczące mądrej elity nie

6 Pouczającą analizę tych tekstów prezentuje Waldron w: J. Waldron, Aristotle's Multitude, w: idem, The Dignity of Legislation, Cambridge University Press, New York 1999, rozdz. 5. 
brzmi zatem „czy jej członkowie są mądrzejsi od innych, ani czy jako grupa są oni mądrzejsi od innych grup?", lecz „czy są mądrzejsi od jakiejkolwiek grupy w ogóle, włączając w to liczniejsze grupy obejmujące także członków tejże mądrej elity?"7

Zdaniem Arystotelesa odrzucenie z góry istnienia osoby na tyle mądrzejszej od pozostałych, że nie może nic zyskać, a tylko stracić przez konsultacje z nimi, jest nieuzasadnione. Przyznaje on, że gdyby takowa osoba istniała, powinna rządzić innymi ${ }^{8}$, jeśli zaś oni ośmieliliby się rządzić nią, to ich rzekoma władza byłaby nieuprawniona i „śmieszna" $(\text { geloios })^{9}$. Epistemiczna wartość licznej grupy decydentów nie jest zatem zjawiskiem na tyle powszechnym, by całkiem delegitymizować epistokrację (nawet zgodnie z rozumowaniem Arystotelesa), choć może znacząco ograniczać jej stosowanie.

Co istotne, nawet przyjmując, że zróżnicowanie uczestników dyskusji ma wartość epistemiczna, nie możemy jeszcze wnioskować stąd, że każdy z nich powinien mieć równy wpływ na kształt ostatecznej decyzji. Po pierwsze, wartość dyskusji nie zależy od przyznania komukolwiek poza mądrą elitą prawa głosu. Opinia innych osób mogłaby być łaskawie uwzględniana przez mądrą elitę, nim zagłosowałaby ona w danej kwestii. Czy w imię maksymalizacji wartości epistemicznej rzetelnej debaty publicznej nie powinniśmy powierzyć toczenia jej, jak też sprawowania władzy politycznej, najmądrzejszym obywatelom? Mill przekonuje, że przyznanie szeregowym obywatelom prawa głosu wpłynie pozytywnie na ich motywację, a poprzez to także na ich zdolności. Z drugiej strony, dlaczego nawet obywatele pozbawieni prawa głosu nie mieliby czuć motywacji do dzielenia się swymi opiniami, skoro będą poprzez nie wpływać na nieliczną grupę rządząca, a w konsekwencji także na kształt ostatecznych decyzji politycznych.

Po drugie, nawet jeżeli (z jakiegoś powodu) uprawnieni do głosowania byliby wszyscy obywatele, argument głoszący wartość uwzględniania bogactwa perspektyw nie implikuje, że głos każdej osoby powinien mieć tę samą wagę. Mill otwarcie stwierdza, że nie powinien.

7 Argument Arystotelesa nie powinien być pomylony z tzw. twierdzeniem Condorceta, które opiera się na zupełnie innych podstawach. Zob. B. Grofman, S. L. Feld, Rousseau's General Will: A Condorcetian Perspective, „The American Political Science Review", vol. 82, 1988, no 2, s. 567-576, gdzie autorzy omawiają twierdzenie Condorceta w kontekście rządów demokratycznych.

8 Arystoteles, Polityka, przeł. L. Piotrowicz, Wydawnictwo Naukowe PWN, Warszawa 2008, $1284 \mathrm{~b} 32$.

9 Ibidem, 1284a4-14. 


\section{Umiarkowana scholokracja Milla}

Nie będziemy oceniać tu powodów, dla których Mill sądził, że każda osoba powinna dysponować przynajmniej jednym głosem. Nie kwestionując tego założenia, uczynimy jego propozycję tym łatwiejszą do przyjęcia dla demokratów. Uczyńmy to zatem przez wzgląd na prowadzoną tu argumentację.

Millowska propozycja głosowania wielokrotnego ma dwa uzasadnienia. Jednym z nich jest zapobieżenie sytuacji, w której pewna grupa lub klasa ludzi mogłaby kontrolować całą sferę polityczną bez zabiegania o czyjekolwiek poparcie. Mill określa to problemem ustawodawstwa klasowego. Skoro najliczniejszą klasą jest zarazem ta słabiej wykształcona i o niższej pozycji społecznej, to można temu częściowo zaradzić poprzez przyznanie osobom o wyższej pozycji możliwości głosowania wielokrotnego. Drugim i równie ważnym uzasadnieniem głosowania wielokrotnego jest uniknięcie sytuacji, w której wielkość wpływu politycznego byłaby całkowicie uniezależniona od zasług, inteligencji itp. Mill uważa za kluczowe, by instytucje polityczne uosabiały w swym duchu przekonanie o większej wartości pewnych opinii nad innymi. Nie stwierdza on co prawda, że dzięki temu będziemy podejmować lepsze decyzje polityczne, ale trudno inaczej rozumieć jego argumentację opartą na tym drugim uzasadnieniu.

Jeśli więc Arystoteles ma rację, twierdząc, że jakość deliberacji jest wprost proporcjonalna do liczby uczestników (przyjmując dla uproszczenia, że wyborcy są uczestnikami deliberacji), to powinniśmy przyznać prawo głosu wszystkim lub przynajmniej wielu obywatelom. Nie dowodzi to jednak jeszcze, że mądrzejsza grupa nie powinna mieć, powiedzmy, dwóch lub trzech głosów. Przyznając im takie dodatkowe głosy, moglibyśmy zrealizować korzyści płynące zarówno z rozbieżności perspektyw, jak i z większej mądrości nielicznych osób. Takie połączenie argumentów platońskich i arystotelesowskich przesądza moim zdaniem o doniosłości Millowskiej propozycji głosowania wielokrotnego. Na jej korzyść przemawia także propozycja uprzywilejowania nie tyle osób mądrych, ile wykształconych. Uznawszy, że władza powinna spoczywać w rękach osób mądrych, staniemy przed poważnym problemem. Jak mianowicie wskazać takie osoby? Problem ten nabierze jeszcze większej wagi, gdy przyjmiemy, że skuteczne uzasadnienie władzy politycznej musi być powszechnie akceptowalne dla rządzonych. W takim wypadku uprzywilejowanie osób mądrych wymagałoby nie tylko, by ich mądrość czyniła z nich lepszych władców, ale także, co dużo trudniejsze, by mądrość ta mogła być uznana przez wszystkich rozsądnych obywateli. Odnoszę się do tej koncepcji uzasadnienia w dalszej partii tekstu. 
Stanowisko Milla jest przekonujące: dobre wykształcenie rozwija w obywatelach zdolność do mądrzejszego rządzenia. Jak więc możemy przeczyć, że grupa osób wykształconych rządziłaby mądrzej od innych? Dlaczego nie powinny one dysponować większą liczbą głosów?

Wiele osób krytykowało propozycję Milla, ale zazwyczaj czyniły to w sposób, który osobiście uważam za niewłaściwy, jak choćby kwestionując tezę, że edukacja szkolna podnosi zdolność do dobrego rządzenia, albo stwierdzając, że równe prawo głosu wynika z prawa do równego traktowania, albo też forsując pogląd, że uprzywilejowanie niektórych osób byłoby moralną zniewagą lub ciosem w samoocenę tych, którym by tego przywileju odmówiono ${ }^{10}$. Ja z kolei proponuję przyjęcie ogólnej koncepcji uzasadnienia politycznego. Zgodnie z nią takie uzasadnienie nie może bazować na twierdzeniach lub doktrynach, które nie sa, w pewnym sensie, powszechnie akceptowalne. Chciałbym wykazać, że powszechnie akceptowalne $w$ tym właśnie znaczeniu jest przekonanie, iż dana społeczność będzie sprawowała tym lepsze rządy, im większa liczba jej członków posiada dobre wykształcenie, nie jest zaś powszechnie akceptowalny pogląd, że pewna wykształcona grupa społeczna wykazuje tendencję do sprawowania lepszych rządów. W ten sposób podważylibyśmy argumentację na rzecz głosowania wielokrotnego bez przyjmowania nieprzekonującej tezy, że dobre wykształcenie nie sprzyja lepszym rządom.

\section{Warunek powszechnej akceptowalności}

Przyjmowana tu, w bardzo ogólnym zarysie, koncepcja uzasadnienia wymaga, by sposób sprawowania rządów był w pewnym sensie powszechnie akceptowalny. Według Rawlsa, uzasadnienie polityczne musi bazować wyłącznie na twierdzeniach i doktrynach akceptowalnych dla wszystkich rozumnych obywateli (lub obywateli-gdy-są-rozumni) ${ }^{11}$. Aby dopełnić ten obraz, Rawls i inni autorzy zaproponowali stosowne koncepcje rozumności. Użycie terminu 'rozumny' rodzi jednak pewne wątpliwości. Ktoś powie, że zbytnio uprzywilejowuje on racjonalistyczne usposobienie lub rodzaj dyskursu. Ktoś inny mógłby uznać go nie tyle za nazbyt ekskluzywny, ile przeciwnie, nazbyt inkluzywny, skoro może odnosić się do osób, które określilibyśmy rozumnymi w potocznej, niefilozoficznej rozmowie. Wolałbym uniknąć rozważania tych kwestii,

10 Zob. R. Arneson, Democratic Rights at National and Workplace Levels; C. Beitz, Political Equality; S. Holmes, John Stuart Mill: Fallibilism, Expertise, and the Politics Science Analogy, w: Knowledge and Politics, red. M. Dascal, O. Gruengard, Westview Press, Boulder, CO 1989.

11 J. Rawls, Liberalizm polityczny, przeł. A. Romaniuk, Warszawa 2012, s. 198-199. 
odnosząc się tu w sposób bardziej ogólny do dopuszczalnych i niedopuszczalnych podstaw krytyki, zamiennie z rozumnymi i nierozumnymi, pozostawiając otwartą kwestię tego, które podstawy krytyki są dopuszczalne, a które nie. Dwie kwestie chciałbym jednak sprecyzować. Z jednej strony żadna podstawa krytyki nie będzie uznana za niedopuszczalną tylko dlatego, że jest błędna. Niektóre błędne poglądy uznam mimo wszystko za dopuszczalne. $Z$ drugiej strony warunkiem uznania pewnej podstawy krytyki za dopuszczalną nie będzie to, że proponuje ją konkretna osoba. Niektóre racje, które ktoś mógłby zgłosić jako podstawę krytyki, zostaną uznane za niedopuszczalne. Można na przykład krytykować pewne uregulowania prawne dlatego, że nie czynią z nas króla lub królowej, bądź dlatego, że przyznają zbyt wielką władzę wróżkom. Są to przykłady niedopuszczalnych podstaw krytyki. Kryterium powszechnej akceptacji, na którym chcę tu oprzeć swą argumentację, w ogólnym zarysie głosi, że władza polityczna powinna być możliwa do uzasadnienia dla osób rządzonych w sposób, którego krytyka jest niedopuszczalna. Musi być ona powszechnie akceptowalna, choć nie każdy powód jej krytyki będzie uznany za dopuszczalny. Nie proponuję tu jednak żadnego ostatecznego rozstrzygnięcia w kwestii tego, które podstawy krytyki są dopuszczalne, a które nie.

Mill kilkukrotnie zauważa, że jego propozycja głosowania wielokrotnego powinna być powszechnie akceptowalna, a nie tylko słuszna. Twierdzi on, że

gdy ten człowiek czuje, że ten drugi lepiej niż on rozumie tę sprawę, nie dziwi go to, gdy zobaczy, że opinia tego drugiego w większej jest cenie niż jego opinia i zdaje mu się, że się to zgadza ze zwyczajnym biegiem rzeczy. Trzeba tylko, żeby przyczyny tej wyższości były dla niego zrozumiałe i żeby je mógł uznać za stuszne ${ }^{12}$.

Taka potrzeba („trzeba tylko”) wyraźnie odróżnia ów pogląd od stanowiska głoszącego, że faktyczna wyższość pewnej osoby wystarczy do uzasadnienia jej większego wpływu politycznego. Nie wymaga ona bowiem przyzwolenia każdej jednostki z osobna. Wymaga ona nieco mniej. Przywodzi na myśl zasadę Rawlsa, że wszystkie wyznawane doktryny powinny być akceptowalne dla wszystkich rozumnych osób. Mill nie rozstrzyga jednak definitywnie, czy chodzi mu o takie właśnie stanowisko moralne, czy może tylko o Arystotelesowski, pozornie pragmatyczny argument, że każde inne rozwiązanie będzie miało „pełno nieprzyjaciół"13. Mill pisze poza tym, że

12 J. S. Mill, O rzadzie reprezentacyjnym, przeł. G. Czernicki, Wydawnictwo Dzieł Tanich i Pożytecznych: Drukarnia "Czasu” W. Kirchmayera, Kraków 1866, s. 134 (podkreślenie moje - D. E.).

13 Arystoteles, Polityka, $1281 \mathrm{~b} 31$. 
[...] byleby oddziały i stopniowanie [siły głosu] nie były stanowione dowolnie, ale w taki sposób, iżby je sumienie i rozum publiczny mogły zrozumieć i uznać za słuszne. [...] Przywilej przystępny dla wszystkich, którzy zdołają dowieść, że zadość uczynili wszystkim warunkom, na których przywilej ten spoczywa w teorii i w zasadzie, nie obrażałby niczyjego uczucia sprawiedliwości $[\ldots]^{14}$.

Ten fragment sugeruje, że Mill stosuje warunek powszechnej akceptowalności.

\section{Dylemat}

Można twierdzić, że w przypadku większości kandydatów na epistokratów istnieją takie powody odmówienia im rzekomej ekspertyzy, które powinny być uznane za dopuszczalne. Kwestia wskazania osób będących w posiadaniu kluczowej wiedzy moralnej stanowi przedmiot zażartego sporu, w którym wszystkie strony mają rozsądne argumenty na poparcie swych tez. Krytyka poglądu, że papież dysponuje wiedzą moralną (w przyjmowanym tu znaczeniu), nawet jeśli ów pogląd jest prawdziwy, nie jest ani szalona, ani nikczemna, a w każdym razie nie jest wystarczającym powodem, by odmówić komuś prawa do bycia rządzonym na akceptowalnych dla niego podstawach. Jest to założenie mojej argumentacji, którego nie będę tu dowodził. Nie będę także starał się (co już stwierdziłem wcześniej) precyzować charakteru zarzutów dopuszczalnych. Jeśli zaakceptujemy zakaz czynienia krzywdzących porównań (jak będę określał odwołania do wyjątkowej mądrości niektórych obywateli), może on stanowić podstawę krytyki propozycji epistokratycznych.

Może jednak wydawać się, że zakaz czynienia krzywdzących porównań kłóci się z innym twierdzeniem, które wiele osób uzna za niezmiernie przekonujące, a nawet niepodlegające rozsądnej dyskusji:

Wartość Polityczna Wykształcenia: dobrze wykształcone społeczeństwo w zasadzie wykazuje tendencję do mądrzejszego rządzenia.

Nie rozstrzyga się tu, jaki rodzaj wykształcenia ma ową wartość, ale zgodzę się ze zwolennikami scholokracji, że istnieje pewien typ wykształcenia, w odniesieniu do którego byłoby nierozsądne czy też niedopuszczalne (w przyjmowanym tu znaczeniu) zaprzeczyć, że społeczność tak wykształcona będzie wykazywała tendencję do mądrzejszego rządzenia. Oto kilkoro kandydatów, których można uznać za przekonujących

14 J. S. Mill, O rzadzie reprezentacyjnym, op. cit., s. 136. 
$\mathrm{w}$ tej roli, osobno lub w jakiejś konfiguracji: umiejętność pisania i czytania, podstawowa wiedza na temat funkcjonowania rządu, szczypta wiedzy historycznej, wiedza o odmienności sposobów życia członków danego społeczeństwa, nieco wiedzy ekonomicznej, nieco wiedzy dotyczącej praw i obowiązków własnych i innych osób, podstawowa wiedza o konstytucji własnej wspólnoty politycznej itp. Gdyby (z czym jestem skłonny się zgodzić) przy stosownym dookreśleniu „dobrego wykształcenia" Wartość Polityczna Wykształcenia okazała się niepodatna na dopuszczalną krytykę, przemawiałoby to na korzyść mojego oponenta, zwolennika przyznania dodatkowych głosów osobom wykształconym. Przyjmijmy więc tę tezę na użytek prowadzonej tu argumentacji ${ }^{15}$.

Będę utrzymywał, że nawet jeżeli Wartość Polityczna Wykształcenia znajduje się poza dopuszczalną krytyką, to i tak można przeczyć w dopuszczalny sposób następującej tezie:

Teza Scholokratyczna: W sytuacji, gdy niektóre osoby są dobrze wykształcone, inne zaś nie, państwo byłoby lepiej rządzone, gdyby osoby dobrze wykształcone dysponowały większą liczbą głosów.

Pozornie nieproblematyczne przejście od Wartości Politycznej Wykształcenia do Tezy Scholokratycznej może być w rozsądny sposób krytykowane, a w związku z tym zakaz czynienia krzywdzących porównań na korzyść lepiej wykształconych obywateli ostałby się nietknięty. Myślę, że idea Millowska jest największym wyzwaniem dla takiego zakazu.

\section{Zarzut demograficzny}

W społeczeństwie, w którym niektóre osoby otrzymały odpowiednie wykształcenie, inne zaś nie, te wykształcone wcale nie muszą w ogólnym rozrachunku, potrafić rządzić mądrzej od pozostałych, a to ze względu na pewne epistemicznie szkodliwe cechy charakteryzujące tę grupę. Dla wyjaśnienia przyjmijmy, że z jakiegoś powodu ludzie, którzy zabiegali o wykształcenie, statystycznie rzecz biorąc mieli bardziej rasistowskie poglądy od innych, a nie zmieniło się to nawet po zdobyciu przez nie wykształcenia. Ich rasizm niwelowałby w takiej sytuacji korzyści epistemiczne uzyskane dzięki wykształceniu.

Ogólna postać krytyki powierzania osobom wykształconym większej ilości głosów, która równocześnie daje się wszakże pogodzić ze

15 Gdzie indziej (D. Estlund, Making Truth Safe for Democracy, w: The Idea of Democracy, red. D. Copp, J. Hampton, J. Roemer, Cambridge 1993, s. 71-100) byłem skłonny raczej temu przeczyć. Tutaj dopuszczam możliwość, że argumentom epistokratycznym można oponować nawet bez takiego przeczenia. 
stwierdzeniem, że dobre wykształcenie podnosi zdolność do mądrego rządzenia, brzmi zatem następująco:

Zarzut Demograficzny: wykształcona część społeczeństwa może, dysproporcjonalnie do jego reszty, mieć epistemicznie szkodliwe cechy, które niwelują niewątpliwe korzyści epistemiczne związane z posiadaniem wykształcenia.

Sprzeciw wobec Millowskiej idei wielokrotnego głosowania przez osoby lepiej wykształcone często przybiera tę właśnie ogólną postać. Wskazuje się wówczas, że $\mathrm{w}$ naszym społeczeństwie przywilej bycia wykształconym przynależy $\mathrm{w}$ nieproporcjonalnym stopniu członkom pewnych ras, klas i (do niedawna) płci. Nawet w społeczeństwie bardziej idealnym od naszego mogłyby występować pewne wzorce demograficzne, które sprawiałyby, że pula osób starających się o przyjęcie na studia byłaby statystycznie niereprezentatywna. Nawet przyjmując (co czynimy na potrzeby argumentacji), że każdy postępuje raczej z dobrą wolą, niż lekceważąc interesy innych osób, ludzie są nieuchronnie stronniczy ze względu na swą rasę, klasę i płeć. Przyznanie większej liczby głosów jednej z tych grup tylko spotęguje efekt takich uprzedzeń, obniżając jakość decyzji zbiorowych.

Co prawda kwestie tego, co dokładnie rozumiemy tu przez stronniczość, i w jaki sposób przekłada się ona na błędność decyzji zbiorowych, wymagają bardziej szczegółowego rozważenia, ale mimo to uznaję powyższe rozumowanie za potężny argument przeciwko przyznawaniu dodatkowych głosów absolwentom szkół wyższych, a nawet osobom o jakimkolwiek wykształceniu formalnym. Stanowi ono także jedną z najlepszych linii krytyki testów na umiejętność czytania i pisania stosowanych niegdyś w południowych stantach USA, zakazanych zaś przez Ustawę o prawach obywatelskich (Voting Rights Act) z 1965 roku $^{16}$. Wiele osób sprzeciwiało się takim testom w sposób mniej epistemiczny, zwłaszcza odwołując się do bezstronności proceduralnej, ale można także krytykować je w sposób epistemiczny. Pośrednie pozbawienie praw wyborczych biednych czarnoskórych mieszkańców amerykańskiego Południa poprzez formalne pozbawienie praw wyborczych obywateli, którzy nie zdali testów czytania i pisania, można bowiem uznać za rezultat (celowego) zlekceważenia epistemicznej doniosłości demografii rasowej, związanej w tamtym konkretnym czasie i miejscu z umiejętnością czytania i pisania. Odgrywa to istotną rolę nawet, jeśli nie doszło do naruszenia bezstronności proceduralnej (jak musiał sądzić Mill), i nawet gdybyśmy mogli przyjąć, że ludzie uprawnieni do głosowania bezstron-

16 Zob. The Law of Democracy, red. S. Issacharoff et al., The Foundation Press, Westbury, NY 1998, s. 58 (przypis 29). 
nie uwzględnialiby interesy wszystkich osób na tyle, na ile pozwalałyby im posiadana wiedza i doświadczenie.

Sprzeciw wobec pomysłu przyznania osobom wykształconym możliwości głosowania wielokrotnego nie wymaga, by wszyscy uprawnieni (np. rozsądni) obywatele zaakceptowali epistemiczne tezy składające się na argument demograficzny. Wystarczy, że stawianie tych tez nie jest niedopuszczalne (nie jest nierozsądne). W takim wypadku można rozsądnie przeczyć temu, że osoby wykształcone w tej konkretnej sytuacji będą potrafiły rządzić mądrzej od pozostałych. Argument ten skutecznie podważa zasadność epistokracji, nawet gdy uznamy za dopuszczalną jego krytykę oraz trwanie przy stanowisku, że osoby wykształcone - nawet jeśli są $\mathrm{w}$ nieproporcjonalnym stopniu białe, zamożne i płci męskiej - prawdopodobnie będą rządziły mądrzej od innych. Fakt rozsąności takiego przeczenia ma znaczenie fundamentalne (nawet jeśli rozsądna jest także akceptacja poglądu przeciwnego), zgodnie z przyjętym przez nas wymogiem, by uzasadnienie metody sprawowania władzy było, w tym właśnie znaczeniu, powszechnie akceptowalne.

Demograficznego zarzutu wobec przyznawania większej liczby głosów osobom wykształconym można jednak uniknąć, korygując demograficznie grupę, która otrzymuje dodatkowe głosy. Jeśli problemem jest niedostateczna reprezentacja pewnych grup rasowych, klasowych lub płci, to można wyselekcjonować spośród osób wykształconych ich podzbiór, w którym będą one stosownie reprezentowane (powiedzmy, ze względu na ich procentową obecność w społeczeństwie). (Oczywiście konieczne jest, by istniała odpowiednia liczba wykształconych członków tych grup. Załóżmy jednak, że tak właśnie jest.) Taki krok pozbawiłby sceptyków podstaw do zwątpienia w epistemiczną wyższość grupy, której przyznano większą liczbę głosów. Czy podważyłoby to stosowalność zarzutu demograficznego?

Przyjmijmy, że pewien niedowiarek wskaże, że choć skorygowano demograficznie taką uprzywilejowaną grupę pod względem rasy, klasy i płci, to nie uczyniono tego w odniesieniu do wyznania. Moglibyśmy sprawdzić empirycznie, czy poszczególne grupy wyznaniowe są niedostatecznie reprezentowane. Następnie, gdyby faktycznie tak było, moglibyśmy dokonać stosownych korekt w grupie osób wykształconych. Problem rozwiązany. Co jednak, spytałby ten sam niedowiarek, z orientacją seksualną? OK, możemy sprawdzić i tę kwestię, a jeśli to konieczne, wyeliminować także ten problem.

Teraz jednak przyjmijmy, że pewien inny niedowiarek stwierdzi, że $\mathrm{w}$ naszej uprzywilejowanej grupie istnieje nieproporcjonalnie wielu rasistów i seksistów. Weryfikacja empiryczna tej tezy, nawet jeśli jest ona prawdziwa, może okazać się niemożliwa, przynajmniej w praktyce. Nazwijmy cechy tego typu empirycznie ukrytymi. Fakt ich niepoznawalności empirycznej nie wystarcza jednak do tego, by uznać zarzut naszego nie- 
dowiarka za niedopuszczalny. Naturalnie nie określamy tu precyzyjnie kryteriów dopuszczalności i niedopuszczalności zarzutów, więc nic tu nie jest do końca oczywiste.

Bez wątpienia jednak do uznania poglądu za dopuszczalny nie wystarcza to, że nie można go obalić empirycznie. Wielu szalonych poglądów na temat duchów, spisków czy motywów nie sposób zweryfikować empirycznie, co nie czyni ich mniej szalonymi. Jednak pogląd, jakkolwiek dyskusyjny, zgodnie z którym skorygowana demograficznie grupa osób wykształconych wciąż może zawierać nieproporcjonalnie wielu rasistów, seksistów lub osoby z innymi niemożliwymi do sprawdzenia uprzedzeniami, do nich nie należy. Być może nie jest on mniej rozsądny niż twierdzenie przez kogoś, że osoby wykształcone są w nieproporcjonalnym stopniu liberalne lub konserwatywne (i że prowadzi to do niekorzystnych skutków epistemicznych), zanim jeszcze istniała możliwość przedstawienia empirycznego dowodu w tej kwestii. Można przynajmniej mieć solidne (nawet jeśli nie bezdyskusyjne) podstawy, by tak sądzić - podstawy nieoparte na nastrojach antyspołecznych lub jawnie szalonych poglądach - choć nie wystarcza to jeszcze do ostatecznego rozstrzygnięcia naszego problemu. Pytanie brzmi bowiem: jeśli czyjś zarzut odwołuje się do rzekomo empirycznie ukrytych cech, na jakiej podstawie można uznać go za niedopuszczalny? Nie daję tu żadnej definitywnej odpowiedzi na to pytanie. Sugeruję jedynie, że często może brakować podstaw wystarczających do uznania zarzutów tego typu za niedopuszczalne.

Pójdźmy w naszym rozumowaniu dalej. Przypuśćmy, że ktoś diagnozuje nie tyle występowanie jakiegoś konkretnego wypaczenia demograficznego, ale uważa po prostu, że takie wypaczenie mogłoby występować. Nie podejrzewa on, by chodziło akurat o rasizm czy seksizm, ale dopuszcza, że demograficznie skorygowana grupa osób wykształconych wciąż w nieproporcjonalnym stopniu posiada pewną cechę epistemicznie wypaczająca, która zawsze towarzyszy wykształceniu, a poprzez to pośrednio i nieintencjonalnie zostaje uprzywilejowana $\mathrm{w}$ takim systemie. Nazwijmy cechy tego typu domniemanymi.

Przypuśćmy, że okazałoby się, iż osoby lepiej wykształcone są również (z wielu skomplikowanych powodów) bardziej sfrustrowane seksualnie. Przyjmowaliśmy wcześniej, że ta konkretna grupa zasadniczo potrafi rządzić mądrzej niż grupy nieposiadające dobrego wykształcenia. Założenie to okazuje się jednak nieuprawnione, skoro osoby sfrustrowane seksualnie mogą rządzić na tyle gorzej od innych, że niweluje to korzyści płynące z ich wykształcenia. Mogą one na przykład czuć wstręt do własnej seksualności i sprawować rządy irracjonalnie purytańskie. Jeśli dopuścimy taką możliwość, możemy rzecz jasna próbować zweryfikować ją empirycznie (zbadać np. czy rządy osób wykształconych faktycznie są bardziej purytańskie). Jednak nie odeprzemy w ten sposób 
argumentu, że może występować taka cecha towarzysząca wykształceniu, która błędnie nie jest uznawana za demograficznie istotną, a która z perspektywy rządzenia politycznego niweluje korzyści związane z wykształceniem. Przyjmujemy, że nie jest to cecha, której wpływ na sposób głosowania znamy lub która jest możliwa do sprawdzenia.

Rozważmy zatem zmodyfikowane kryterium piśmienności jako podstawę przyznania prawa głosu: spośród osób piśmiennych wybierzmy reprezentatywną demograficznie próbę, usuwając błąd statystyczny związany z rasa, klasą oraz płcią. Uczyniwszy to, przyznajmy dwa głosy wszystkim członkom takiej skorygowanej grupy i połowę tej liczby wszystkim niepiśmiennym obywatelom (oraz osobom, które zostały wykluczone $\mathrm{z}$ naszej grupy w rezultacie jej korekty rasowej, klasowej i ze względu na płeć). W takim wypadku, dające się zidentyfikować przyczyny potencjalnej stronniczości próby zostałyby usunięte, zachowane zaś zostałyby korzyści związane ze zdolnością pisania i czytania jej członków. Takie rozwiązanie wydaje mi się nie do przyjęcia. Moim zdaniem zarzuty wobec niego, bazujące na przypuszczeniu, że wciąż mogą istnieć istotne błędy próby, których jesteśmy nieświadomi, nie są tak nierozsądne, byśmy mogli uznać je za niedopuszczalne. W mojej opinii jest to ostateczny argument przeciwko temu rozwiązaniu. Skoro zaś znajduje on zastosowanie w odniesieniu do kryterium piśmienności, to dlaczego nie miałby stosować się także do kryterium wykształcenia?

Dlaczego mielibyśmy ignorować wątpliwości związane z cechami domniemanymi? Oczywiście, nie można automatycznie uznawać za dopuszczalne tego, czego nie można sfalsyfikować empirycznie. Z drugiej strony, uwzględniwszy historię rzeczywiście funkcjonujących systemów politycznych, które uprzywilejowywały pewną grupę obywateli, wątpliwości takie nie muszą być wcale szalone lub wynikać ze złej woli.

Wniosek jest taki: jeśli zarzuty oparte na występowaniu ukrytych i/lub domniemanych cech grupy uprzywilejowanej nie są całkowicie niedopuszczalne (zaś jeśli sa, to na jakiej podstawie?), to epistemiczny argument za uprzywilejowaniem skorygowanej pod kątem reprezentatywności grupy osób wykształconych nie mógłby uzasadnić takiego rozwiązania politycznego, nawet gdyby wszyscy zgodzili się, że rozpatrywany tu typ wykształcenia (zasadniczo) czyni osoby je posiadające mądrzejszymi władcami.

\section{Zarzut stronniczości jako zarzut demograficzny}

Może się wydawać, że prostszym argumentem przeciwko przyznaniu osobom wykształconym, czy też jakiejkolwiek innej grupie, większej liczby głosów jest ten, że każda osoba kieruje się korzyścią własna, a więc takie rozwiązanie bezpodstawnie faworyzowałoby interesy gru- 
py uprzywilejowanej. Takie kierowanie się korzyścią własną mogłoby przeważyć epistemiczne profity wynikające z wykształcenia. Abstrahując od kwestii demograficznych, może się wydawać, że żadna grupa nie powinna móc uprzywilejowywać siebie w ten sposób. Jak się okazuje, ta postać zarzutu nie różni się od zarzutu demograficznego, przynajmniej jeśli decyzje osób rządzących przyjmują kształt powszechnych praw, obowiązujących wszystkich obywateli.

Załóżmy najpierw, że nie ma żadnych podstaw, by sądzić, iż osoby wykształcone posiadają jakikolwiek zestaw właściwych tylko sobie interesów - że pod względem interesów są losowo dobraną próbką społeczeństwa. W takiej sytuacji fakt, że mają one większą władzę od innych nie oznacza, że ich decyzje będą sprzyjały jakimś konkretnym interesom. Będą sprzyjały wyłącznie losowej próbce interesów, a więc jeśli tylko owa uprzywilejowana grupa nie jest zbyt mała, żadne interesy nie będą faworyzowane.

Oczywiście, jeśli wykształcenie cechuje wyłącznie osoby bogate, mężczyzn lub osoby białe, to jest wielce prawdopodobne, że systematycznie łączą je pewne interesy: ich interesy znacząco różnią się od interesów losowo dobranej grupy o tej samej wielkości. W takim przypadku przyznanie osobom wykształconym większej liczby głosów sprzyjałoby realizacji konkretnych interesów.

Zarzut stronniczości stanowi więc odmianę zarzutu demograficznego. Zgodnie $\mathrm{z}$ nim uprzywilejowana grupa jest statystycznie niereprezentatywna, a zatem stronnicza w sposób, który przeważa wszystkie epistemiczne zalety, jakie mogłaby posiadać. Ogólny zarzut demograficzny jest jednak silniejszy, ponieważ stosuje się on nawet w (nierealistycznym) przypadku, w którym nie występuje żadna znacząca stronniczość w motywacjach ludzi. Wyjaśniałby on zatem, w jaki sposób możemy kwestionować Millowską ideę głosowania wielokrotnego nawet wyeliminowawszy zagrożenie stronniczością. Jeśli uprzywilejowana grupa jest stronnicza, oznacza to, że albo jej członkowie kierują się pewnymi szczególnymi pobudkami, albo ich całkowicie zwyczajne pobudki sprzyjają jej statystycznie nietypowym interesom. W innym przypadku stronniczość w ogóle by nie wystąpiła.

\section{Czy można rozsq̨dnie kwestionować epistemiczna wartość równego prawa głosu?}

Wskazywałem, że pomysł różnicowania siły głosu obywateli na skutek dokonania krzywdzących porównań epistemicznych może stanowić przedmiot dopuszczalnej krytyki. Taka teza może wyglądać na przyczynek do bardziej ogólnej obrony równej siły głosu przed zagrożeniem ze strony epistokracji. Rozważmy argumentację na rzecz przyznania nie- 
którym grupom formalnie nierównej siły głosu, ale bez uciekania się do krzywdzących porównań epistemicznych. Załóżmy na przykład, że elektorat wiejski ma prawo głosu tylko w niektórych wyborach, do których upoważniony jest elektorat miejski. Powodem wprowadzenia takich regulacji może być umożliwienie owym wyborcom wykonywania innej pracy (uprawiania roli, itp.), której społeczeństwo od nich oczekuje. Nie ma więc tu mowy o żadnym krzywdzącym porównaniu epistemicznym. Czy w związku z tym możliwa jest epistemiczna krytyka postulatu przyznania elektoratowi wiejskiemu mniejszej siły głosu? Czy można twierdzić, że osłabienie władzy mieszkańców obszarów wiejskich sprawi, iż decyzje polityczne będą uprzywilejowywały mieszkańców miast? Byłaby to epistemiczna krytyka przyznania im mniejszej siły głosu.

Powyższa argumentacja wydaje się równie wadliwa co ta, zgodnie z którą osoby wykształcone potrafią rządzić mądrzej. Stwierdzenie, że wiejski punkt widzenia naznaczony jest wartością epistemiczna, a w największym stopniu zna go właśnie elektorat wiejski, ufundowana jest na krzywdzącym porównaniu. To prawda, że, ogólnie rzecz biorąc, elektorat wiejski zwykle nie jest uważany za mądrzejszy od innych grup, a jeśli już, to tylko pod pewnymi względami. Nawet jednak takie złagodzone krzywdzące porównanie jest podatne na zarzut występowania ukrytych czy domniemanych cech, które niwelowałyby wszelkie korzyści epistemiczne. Nawet jeśli, ogólnie rzecz biorąc, wyborcy wiejscy dysponują pewną wyjątkową wiedza, to nie jest nierozsądną obawa, że zamieszkiwanie terenów wiejskich skutkuje swoistym brakiem wrażliwości lub ograniczeniami, które zasadniczo niwelują epistemiczną wartość takiej wiedzy. (Być może elektorat wiejski jest bardziej przywiązany do tradycji lub też wykazuje irracjonalne upodobanie do otwartych przestrzeni, itp.)

Jednym z przykładów tego typu odwołania do wyjątkowej wiedzy posiadanej przez pewną grupę osób jest twierdzenie, że ofiary niesprawiedliwości wykazują szczególne predyspozycje do pojmowania wymogów sprawiedliwości. Mój argument demograficzny kwestionuje poprawność takiego rozumowania, uznając je za podlegające rozsądnym sporom. Zachęca on do refleksji nad różnego rodzaju niepożądanymi cechami charakteru, które mogą towarzyszyć wyjątkowej wiedzy na temat wymogów niesprawiedliwości, jaką posiadają ofiary.

Jeśli argumentacje za przyznaniem lub za odmówieniem obywatelom równej siły głosu mają stanowić przedmiot dopuszczalnych sporów, nie mogą one opierać się na krzywdzących porównaniach epistemicznych. Gdyby naszym celem była obrona formalnie równej siły głosu każdego obywatela, bylibyśmy zmuszeni do rozważań nieepistemicznych, zaproponowania jakiejś koncepcji sprawiedliwości proceduralnej lub równego szacunku. Wówczas rola wymiaru epistemicznego argumentacji mogłaby znacząco zmaleć. Moim celem jednak nie jest ani obrona 
formalnie równej siły głosu, ani jej krytyka. Moim skromnym zadaniem jest krytyka Millowskiej idei przyznania dodatkowych głosów osobom wykształconym przez wzgląd na ich większą mądrość. (Mam też, rzecz jasna, nadzieję, że argumentacja ta znajduje dużo szersze zastosowanie w krytyce różnych postulatów epistokratycznych.)

Ktoś mógłby jednak sądzić, że podjęcie nieepistemicznych rozważań moralnych dla uzasadnienia postulatu przyznania obywatelom równej siły głosu jest nieuniknione, moje stanowisko zaś to swoisty unik. Można by stąd wnioskować, że tak naprawdę chcę bronić równej siły głosu wszystkich obywateli. Nie taki jest mój zamiar. Widzę co najmniej dwa rodzaje formalnie nierównych zasad głosowania, co do których nie jestem pewien, czy chciałbym je odrzucić: (1) formalnie większa siła głosu posiadana przez ustawodawców pochodzących z wyboru, przez wyznaczonych urzędników, sędziów itp. oraz (2) formalnie większa waga głosu uzasadniona różnego rodzaju podziałami administracyjnymi, na przykład większa władza mieszkańca Rhode Island niż nowojorczyka przy ustalaniu składu Kongresu oraz w wyborach prezydenckich ${ }^{17}$.

Tak więc ten sam argument, przy użyciu którego krytykowałem Millowską ideę głosowania wielokrotnego, może stanowić podstawę odmowy przyznania równej siły głosu pewnej grupie, która rzekomo dysponuje wyjątkową wiedzą. Równość pod względem siły głosu to jednak wątpliwy ideał, a jej obrona w żadnym razie nie jest moim celem w niniejszym artykule.

\section{Podsumowanie}

Wielu myślicieli (najbardziej znanym jest Rawls) obierało za cel uzasadnienie metody sprawowania rządów w sposób powszechnie akceptowalny dla osób rządzonych (nie uwzględniając, rzecz jasna, ewentualnych zarzutów nierozsądnych). Nie jest jasne, czy epistokratyczne koncepcje Platona, Arystotelesa i Milla mogłyby sprostać temu wymagającemu kryterium. Zapewne największe szanse na to ma Millowska idea przyznania większej liczby głosów osobom wykształconym. Jeśli przyjmiemy, że wykształcenie, jakkolwiek pojmowane, czyni z obywateli mądrzejszych decydentów w kwestiach politycznych, to jak możemy zaprzeczyć, że grupa osób wykształconych będzie sprawowała rządy mądrzej od innych? Nawet jeśli istnieją dobre powody przyznania

17 Pozbawienie praw wyborczych dzieci to kolejna postać formalnej nierówności, której zasadności skłonny jestem bronić. $Z$ uwagi na fakt, że często bazuje ona na omawianych tu przeze mnie krzywdzących porównaniach, stanowi znaczące wyzwanie dla mojej argumentacji, na co wskazała mi uwagę Francis Shrag. Brak miejsca uniemożliwia mi rozwinięcie tu tego problemu. 
każdemu wyborcy jednego głosu, dlaczego mielibyśmy nie przyznać osobom wykształconym większej ich liczby? W mojej opinii pogląd ten można rozsądnie odrzucić, nawet jeśli wykształcenie faktycznie przekłada się na zdolność do mądrego rządzenia. Sądzę, że nie jest nierozsądne mniemanie, iż grupa osób wykształconych różni się pod względem demograficznym od reszty społeczeństwa w sposób, który niweluje korzyści płynące $\mathrm{z}$ jej wykształcenia (jak w przypadku różnic rasowych, genderowych czy klasowych). Jeżeli nawet scholokracja w umiarkowanej wersji Milla nie daje się obronić w powszechnie akceptowalny sposób, wątpię, czy jakakolwiek forma epistokracji była możliwa do obrony ${ }^{18}$.

Przekład i opracowanie naukowe: Janusz Grygieńć et al. ${ }^{19}$

\section{Streszczenie}

\section{Dlaczego nie epistokracja?}

John Stuart Mill sądzil, że wyjątkowa mądrość pewnej grupy mniejszościowej usprawiedliwia przyznanie jej większej władzy politycznej. Twierdził on, że obywatele lepiej wykształceni powinni dysponować większą liczbą głosów od reszty, nawet jeśli każdy obywatel powinien mieć prawo głosowania. Nie zamierzam stosować tu dość rozpowszechnionego argumentu, zgodnie z którym choć bez wątpienia osoby wykształcone mogłyby rządzić mądrzej od innych, to względy równego szacunku lub bezstronności proceduralnej bezpośrednio i kategorycznie przemawiają przeciwko przyznaniu niektórym ludziom większej liczby głosów niż pozostałym. Nie przeczę (ani też nie zgadzam się), że osoby wykształcone dysponują przypisywaną im przez Milla mądrością lecz nie zgodzę się, że teza ta może uzasadniać nierówną dystrybucję władzy politycznej. W każdym razie moim celem jest $\mathrm{w}$ tym samym stopniu wyjaśnienie Mil-

18 Praca ta nie powstałaby, gdyby nie urlop naukowy oraz Salomon Research Award przyznane mi przez Brown University, jak też Harsanyi Fellowship in Social and Political Theory odbyte w Research School of Social Sciences na Australian National University. Jestem wdzięczny za dyskusje dotyczące wykształcenia i mądrości politycznej z członkami Grad Student Philosophy Club na Brown University oraz te przeprowadzone podczas konferencji poświęconej Terry'emu Pennerowi z Terrym, Paulem Warrenem i innymi osobami. Miałem przyjemność uczestniczyć także w owocnej debacie dotyczącej omówionych tu zagadnień w Centre for Applied Philosophy and Public Ethics na Australian National University. Dziękuję także wydawcom oraz recenzentom niniejszego tomu za ich trafne komentarze.

19 [Współautorzy przekładu: Marek Al Sofij Han Ardabili, Justyna Bendyk, Jakub Dobrzyński, Kajetan Gendek, Jakub Gużyński, Damian Jabłoński, Liwia Jezierska, Bartłomiej Kuczkowski, Anna Kuszmiruk, Olaf Michalski, Marta Rólka, Bartosz Stolarski, Adam Szefler, Krzysztof Tarkowski, Mateusz Wiśniewski.] 
lowskiej koncepcji scholokracji, docenienie jej wagi jako wyzwania rzuconego zasadzie równej siły głosu obywateli, jak też jej krytyka.

Słowa kluczowe: epistokracja, uzasadnienie polityczne, demokracja epistemiczna, scholokracja

\section{Summary}

\section{Why Not Epistocracy?}

John Stuart Mill argued that the superior wisdom of an identifiable minority justified their having greater political authority. In particular, Mill thought, citizens with a high degree of education ought to have more votes than others, even if all ought to have the right to vote. My strategy is not the more familiar one of arguing that even though we must grant that the educated might rule more wisely, there are reasons of equal respect or procedural fairness that directly and decisively preclude giving some citizens more votes than others. I will not deny (nor accept) that the educated have the superior wisdom Mill's argument supposes, but deny that such a claim is available as a justification for unequal political authority. In any case, my aim is as much to explain and acknowledge the challenge posed by Millean scholocracy as it is fully to answer it.

Keywords: epistocracy, political justification, epistemic democracy, scholocracy 